PATRICIA PFEIL*

University of Applied Sciences Kempten

UDO DENGEL**

University of Applied Sciences Fulda

MARION MÜLLER***

South German Institute of Empirical Social Research e.V., Munich

DOI: $10.26485 / \mathrm{PS} / 2017 / 66.4 / 2$

\title{
CULTURAL-SPECIFIC DIMENSIONS \\ OF SOCIETAL RE-FORMATION WITHIN THE GERMAN MIDDLE CLASS
}

\begin{abstract}
The article examines ways of re-formation of the (German) middle class caused by the perception of social (and individual) crises (in our example over-indebtedness) and associated uncertainty. Which are the strategies that middle-class members develop to cope with those perceived crises and which factors contribute to the originating of new civic formations? In that context, we emphasize on the impact of culture-specific orientation patterns regarding specific societal groups. We refer to the work of Douglas and Wildavsky [1982] and Cornia, Dressel and Pfeil [2016] and concentrate on the collective dimension in asking, how does the middle class and parts of it like societal subgroups (in our example overindebted people) perceive and interpret social developments and crises (framing)? Which is the relationship between the middle class and institutional actors and the confidence they have in these actors, especially regarding the dealing with social crises and connected solutions? Who do middle-class members blame for the crises and the risks
\end{abstract}

* Prof. Dr; e-mail: patricia.pfeil@hs-kempten.de

** Dr; e-mail: udo.dengel@sk.hs-fulda.de

***Dr; e-mail: marion.mueller@sine-institut.de 
of social decline (blaming)? This is a central question directly connected with the way of dealing with risks and the assumption of responsibility.

Keywords: middle class, social crisis, over-indebtedness, re-formation, German middle class, cultural-specific dimensions, civil society, social risks

This article deals with the question of types of 're-formation' of the insecure (German) middle class in times of crisis. ${ }^{1}$ The aim is to emphasise the influence of cultural-specific orientation on social groups. This is exemplified in the group of overindebted middle-class people. Two perspectives appear to be central: first, the individual perspective and related strategies of these actors, and second, the structural perspective at the level of action in organisations or networks. The focus is on: How does the self-positioning of the middle class change in crisis situations? It is about the dialectics of the social conditions, which are perceived and adopted as 'critical' by the individuals on the one hand, and their reflexive interpretation and acting (re-) formation towards a (new) formation of the middle class on the other. This, in turn, provides opportunities for living together in community and society. In doing so, we focus on the (self-) positioning of the actors as middle-class members in the context of the increasingly complex everyday societal world.

\section{MIDDLE CLASS AND CRISIS}

The middle class is one category of a model of society, which can be subdivided into three classes: the upper, the middle, and the lower. ${ }^{2}$ Of course, society can also be described in more differentiated terms: social milieus, which have been introduced into the scientific discourse with Hardil [2000] and Vester [2001] as well as Schulze [1995] were introduced into the public discourse with the sinus

1 The research group of the author of the Kempten University of Applied Sciences is involved in various projects and work on the subject of social risks. The aim of the Kempten University of Applied Sciences is to give this area the attention it deserves in the current tension between social change and social issues and to broaden the spectrum of research.

2 Already authors of classic sociology deal with the concept 'middle class'. Vogel [2010] provides an overview of their assessments. Common to them (be it Simmel, Bourdieu or Marbach) is that the middle class is a poorly delineated category. The Chicago School tries to handle the problem qualitatively-empirical: in doing so, there can be taken a view over the subjective perspective of potential middle-class members on their life situations as well as on the handling of living conditions. 
studies. They aim to describe society in its sociocultural diversity and to show that, apart from vertical differences, there are also horizontal ones. People differ in their social situation, but they also differ in their basic principles: tradition, modernisation or individualisation and reorientation. These basic orientations form the basis of the social milieus of the centre. Visible here is fear of social exclusion and experiencing fear of losing their attained standards of living as members of the middle class.

In our understanding, a crisis in the middle class, is defined as the consequences of the perception of social crises and the accompanying uncertainty, as described in Feuilletons [cf. Lessenich, SZ of 17/06/2016] or in the sociological science landscape [cf. Burzan 2014, Nachtwey 2016]. The middle class is understood by Müller et al. [2017] as a category of 'relational self-attribution' and at the same time assured social-statistic variables [cf. Müller et al. 2017: 8f.].

Society as we experience it today is characterised by a multitude of social, economic, individual, technological, and political risks, as Beck [1986] described in his book about the risk society. Currently, it is the risk of unemployment, the ever-higher costs of living in the metropolitan area, as well as the refugee crisis, climate change, etc., which are perceived in different ways. The middle class is affected by these risks and feels threatened by the fear of having to rely on welfare state security standards, the reduction of these benefits and the resulting lower legitimacy of the welfare state, which is borne by the middle class.

It is therefore important to ask which innovative, individual, as well as associative ways do middle-class members seek and find and what barriers do they face as civil society actors considering their fear of social decline? With this question, we follow the results of Müller et. al [2017], which identified strategies for the identification of over-indebted middle-class members who were threatened by social descent such as actively changing priorities, defending or not recognising the need for change. On the basis of these findings, it is needed to focus on the categories of action which can be found in the context of civil society and the engagement in civil society. Here we suspect the (re-) formation of middle-class mergers which show solidarity with their own inclusions and exclusions - civil society as both a social framework concept and an analysis concept. ${ }^{3}$ That is to say, we define civil society as a relevant social structure which provides the possibility of the association of middle-class members and at the same time it is precisely these structures of the organisation of collective (or individual/indi-

3 Cf. BMBF application ZiviReform, submitted by the Kempten University of Applied Sciences 2016; further research is planned. 
vidualised) actions of middle-class members which are expected to be categorial results. Civil society is understood as a non-state, non-economic core of voluntary associations and associations of the public [cf. Habermas 1994 [1992]]. Civil society is unbounded [cf. Habermas 1994 [1992]], meaning it excludes neither individuals as actors nor types of the more or less established organisation of actors. We regard civil society as a separate area of action, with its own rules, designed by actors who generate their relevance from living worlds. On the basis of this, we focus on Maaser [2006] and Heidbrink [2006], who place individuals centrally, especially when it comes to taking over responsibility by individuals in society. The individual is involved as a responsible person in this context and is constitutive of civil society as a responsible society: The organisation of the community is increasingly shifted to the responsibility of individuals, similar to what Lessenich formulated with regard to the requirements of the activating state [cf. Lessenich 2009]. Civic, social, civil society commitment, in addition to the increasingly differentiated, empirically based assessment of the individual features mentioned [cf. Dengel 2014], is also discussed in its normative orientation and the analytically open view within the framework of real civil society, including civilian disobedience etc. [cf. Olk and Hartnuss 2011], sometimes also in the attempt to overcome separation between the terms civil society and real civil society [e.g. Conradi 2011]. We accept the ambivalence and ambiguity of the previous elaborations as given in order to let those affected to express their own views. Civil society serves as a structural framework, as a field of action, as a specific mode of action, where associative (new) formations can be explored in the face of crises of the middle class. Last but not least, it is the middle class that is addressed when it comes to social cohesion. 'The middle' of society is to be supporting for the whole of society and seems to be in crisis itself [Lessenich 2009].

\section{COPING WITH SOCIAL RISKS (FRAMING, INSTITUTIONAL TRUST, BLAMING)}

In addition to the framing of civil society, we are working on the basis of the risk culture concept, as introduced by the fundamental work on the relationship between risk and culture by Douglas and Wildavsky [1982]. From a sociocultural perspective, risks cannot be viewed exclusively as an objective dimension, but are presented as a social construct that is spatially and time-bound. We choose the concept of Cornia, Dressel and Pfeil [2016] and use it for exploring the (new) formation of the middle class in times of social transformation and crises by emphasising the influence of cultural orientation on social groups or societies. In 
order to deal with social crises (or perceived crises), three correlated dimensions are used, which can also be applied to the classification of over-indebtedness as a crisis: framing, institutional trust, and blaming strategies. Framing means how people interpret the effects of crises or disasters on their lives. Frames are interpreted as cultural and social interpretative schemata that enable people to organise the world meaningfully by selecting some aspects of perceived reality and combining them into a narrative that allows them a certain interpretation [cf. Entman 2010: 391]. The focus is on the question of how the relationship between members of the middle class, the civil society actors, and e.g. the banking sector or the judiciary, is shaped and the trust they have in this respect, particularly with regard to the handling and resolution of societal crises. A further aspect is the collective dimension; here we will ask how the middle class and parts of it as social subgroups (such as overindebted people) perceive and interpret crises (framing), as groups, not as individuals. The third dimension comes from the question of who is blamed for the dangers of decline and crises - a central question that is directly related to the way in which risks are handled. Particularly interesting is the question of whether differences in blaming strategies can be found or whether they are shaped by cultural-specific ideas which are largely shared by the middle class. Douglas and Wildavsky [1982] refer above all to a "policy of the guilty" to social risks, in which the assignment of blame serves as a kind of "restoration" of the social order - something for which crisis-shaken middle-class members must perform identity work [cf. Müller et al. 2017, Pfeil et al. 2015]. Cornia, Dressel and Pfeil [2016] focus on their consideration of sociocultural differences at the country level with regard to dealing with material risks such as natural catastrophes or crises caused by technical or human failure. This approach involves the different structural, social, and cultural conditions that lead people to behave in different ways in the event of crises.

The discourse that constitutes framing occurs in everyday life: the way people define problems and find causes and explanatory patterns for them is characterised by social structures and cultural values, and at the same time serves the construction of social reality [cf. Berger, Luckmann 1969]. By encouraging or questioning the prevailing patterns of interpretation, people shape their perception of crises or conditions. A crucial aspect arising from the definition of framing, the perception of crises, is the importance of the effectiveness of human interventions: whether people, for example, prioritise the capacity to cope with the crisis and to act as active agents, or, on the contrary, to experience the risks helplessly. Especially with respect to the middle class and its real fears and worries about social decline due to unemployment, too little protection in old age, housing shortages, 
or the fear of individual disadvantages due to politically opening up society for refugees, the significance of this dimension becomes clear - including beyond all disasters. From the research of Cornia, Dressel and Pfeil [2016], it can also be seen that cultural differences influence these perceptions. We did not examine the differences between the cultural and national experiences of different social strata or milieus. Here, research such as that by Douglas and Wildavsky [1982] indicates that middle-class people react extremely sensitively to both potential as well as real individual burglaries when they see themselves robbed of their status.

The second dimension, institutional trust cf. Cornia, Dressel and Pfeil [2016], follows this question of the interpretation of crises. Fundamental trust in public institutions goes with the perception of individual as well as collective (exclusion) fears of the middle class, as Nachtwey details [2016], to cope with this (perceived) crisis situation, or there is a feeling of being left alone - primarily - by state and political institutions or being deceived by other society actors such as banking. This dimension, which also plays a central role in the model by Douglas and Wildavsky [1982], can show differences in the perception of support from institutional actors. The decisive criteria for the respective attitude are the perception of the risk of decline, the acceptance and compliance with the regulations of the public authorities and their evaluation.

Finally, the dimension blaming (the manner of the debt attribution) is included in the model. Here, the attribution of responsibility for relegation and personal destiny to certain addressees is investigated. The focus is on the question of whether individuals are responsible for the crisis, for example, the authorities, those affected, or other entities (such as supernatural powers, accidental misfortunes, fate or natural events) cf. Cornia, Dressel and Pfeil [2016]. As already pointed out by Douglas [2003], the way in which debt is to be credited is a culturally established practice with the normative function of maintaining social order and legitimating social institutions and social ethics. The typical blaming strategies serve to maintain certain ideas of the right social order [cf. Lupton 1999; Tansey, O'Riorden 1999]. There are also specific blaming strategies in the secularised societies of the present, such as the death of a responsible person or an accident caused by the behaviour of a particular person [cf. Douglas, 1992]. The destiny concept of traditional societies is contrasted by a risk concept which can be used to explain "deviations from norms, accidents, and frightening events" [Lupton 1999: 3], since risks are seen as conceptual. For example, "natural" catastrophes, such as Hurricane Irma in September 2017, can be interpreted in traditional societies as an expression of the action of God, whereas in modern societies it is a consequence of human action (or, in the case of "Irma", anthropogenic climate change). In particular, it can 
be seen as negligence on the part of the competent authorities and political actors who have failed to take appropriate preventive measures, for example, measures to safeguard residential areas in flooding areas. The risk-culture concept - in the sense of a culturally elaborated category for coping with uncertainty in a context characterised by secularisation and technological/scientific progress [cf. Wynne 1992], is connected with the notion that the future can be changed by human intervention and that risks therefore imply human responsibility. Although individual interventions can neither prevent banking system crises nor an increasing rate of unemployment, the dangers must be observed and anticipated, and at least appropriate emergency plans prepared, meaning the course of the crisis must be influenced in advance [cf. van Loon 2003; Zinn 2008]. Interventions, therefore, play an important role. The prevailing understanding of 'risk' is strongly based on the formability of the situation and decisions made by governments and the competent authorities, but also by individual persons.

However, it must be asked, to whom the blaming strategies in industrialised societies are directed and which context can be produced with regard to the insecure middle class? Is the middle class responsible itself? Or should the state take responsibility? On the one hand, people in Germany increasingly tend to make political leaders, governments, and offices responsible for the dwindling security and social changes. On the other hand, many researchers have emphasised that, with the increasing spread of neo-liberal individualisation tendencies, a shift of responsibility from the state to the individual citizens takes place, whereby the importance of the self-responsible private initiative generally increases [cf. Halvorsen 1998; Scott 2005; Tulloch 2008]. In the prevailing image of the activating state, the image of a society is depicted in which the latter is responsible for the individual welfare of the citizens, but they have to take responsibility for society in the interests of society and bear responsibility towards society. Thus, the attitude to citizens who cannot or do not want to meet these requirements varies between exclusion and activation.

\section{THE INFLUENCE OF CULTURAL-SPECIFIC ORIENTATION PATTERNS - THE EXAMPLE OF COPING WITH OVER-INDEBTEDNESS}

The following remarks are intended to show how this approach can be made fruitful to grasp the handling of the crisis of the (German) middle class and its re-formation. As mentioned above, the influence of cultural orientation on social groups and the middle class as a social situation should be emphasised. 
We continue to ask what is the relationship between the middle class and institutional actors and about the confidence of the middle class in this relationship, particularly with regard to dealing with and resolving social crises. And finally, to whom is the responsibility for the dangers of social decline and crises attributed (blaming)? This is a central question which is directly related to the way in which risks are handled and responsibility assumed. People from the middle class have so far rarely been in focus when it comes to the issue of over-indebtedness. Nevertheless, these people exist. Our research ${ }^{4}$, which is concerned with the increasing social phenomenon of the overindebted middle class ${ }^{5}$, has been able to show what it means for middle-class people to be insolvent; how they are under pressure when they lose the financial resources that characterise them as members of their class.

A particularly intensive effort is necessary in the middle class. This is reflected, for example, when respondents are confronted with the question of changing themselves due to their financial worries and of being perceived or addressed differently in negotiations with their environment.

We have found, through our work with the identity strategies of overindebted couples from the middle class, that they continue to identify themselves with the values and norms of the middle class, even if they are not part of the middle class in terms of their financial performance [cf. Müller et al. 2017] and the existing institutions barely provide them with a fixed framework for their social location. It is true that milieu concepts suggest new possibilities of social-structural identification of classes, which lie transversely to the conventional understanding of the three-part-division in upper, middle, and lower class. Explicit reference

4 The data come from the project "Identity work under pressure - what practices are used by overindebted people from the middle class to deal with their vulnerable social identity, and which action options and action barriers arise from it?" (2012-2015) which was funded by the German Research Foundation. Data collection and analysis are based on Grounded Theory methodology [Strauss, Corbin 1996]. Mainly narrative-biographical interviews with the same interviewees (mostly couples) at three different points in time and with gain for the development of theory were included successively.

5 We adopt the Chicago-School perspective (see footnote 2 ) by measuring the middle class with social statistics criteria (completed vocational training/ multiannual employment, living in relatively secure conditions until over-indebtedness) before people are included in the sample - but above all, it is the subjective self-assessment of the protagonists who mark the placement in the middle class. In our analysis, we remain open to changes in the self-placement in the middle class and changes in the definition of class itself. In doing so, we recognize new milieu perspectives (Hardil [2000] Vester [2001]) and take account of inequality research, as well as social diagnoses predicting that societies move beyond the class concept [Beck 1986]. 
of our results to existing models is scarcely possible, however, the direction in which (re-) formation as members of a middle class tends is evident from the respective statements of those surveyed. We note the excessive demands on the members of the middle class, who are adhering to middle-class criteria, and thus often become involved in a lasting individualised crisis. They find themselves in a position different from before and are no longer in a position which is believed to be secured, protected from financial material risks, but in a position in which they must reorient themselves. They are forced to re-evaluate their environment or their relationship to the environment or the institutionalised surroundings. How this is to be done is shown in the following by means of a few examples from the results of our study [Müller et al. 2017].

\section{HONORARY OFFICE ${ }^{6}$ AS A FORM OF CIVIL SOCIETY ACTIVITY (FRAMING)}

We ask how people who are overindebted interpret their own debts for themselves, and which ways they find for not falling out of the perceived concept of the middle class. One way of feeling to be a part of the middle class, despite limited financial means and living under formal restrictions of insolvency law, is to continue life as a middle-class member in a different way. One form of this is activity in the honorary office as a form of civil society activity. The honorary office is based on civic engagement, which is still a middle class occupation, not just statistically [e.g. Munsch 2003]. Overindebted middle class members in our study follow the anticipated expectation of a generalised market or work society, they go on in doing as they were before in order to pay back their debts to society. This is shown clearly by statements such as:

It doesn't mean I don't work, just with my feet up. They always see that we do something or I do something (Mr Winkler $\left.22 \mathrm{~m} 1 / 183^{7}\right)$.

To be visibly active has an external effect, by emphasising the tendency to 'stay on the ball' rather than 'pass the ball' to others to take care of it; particularly not the welfare state. The status of the ordinary (middle-class) citizen can only be

\footnotetext{
6 Honorary office stands for the German term 'Ehrenamt' which has a special tradition in Germany in the field of voluntary commitment.

7 Notation: 22 means couple no. 22 (consecutive numbering), $\mathrm{m}$ stands for male, $\mathrm{w}$ for female, 1 indicates the point in time in which the interview was conducted, 183 stands for the line number of the beginning of the quote in the interview. The interviews were conducted in German, relevant quotations have been translated for the scope of this article by the authors.
} 
obtained, if (at the least) it is indicated that one's own doing is enough to provide for itself: "on the consolidation of the status of employment (achieving) a social citizenship status" [Castel 2005: $41^{8}$ ]. If the acquisition ceases, it will be necessary to hold on to alternatives in class and status. Civil engagement seems to offer such an alternative. In the labour market as well as in the field of civic engagement, individuals increasingly shape themselves into "the form and content of their paid and unpaid activity" [Hacket et al. 2004: 289]. And in the changed working world, in which demarcations between work and commitment/civil work are weakened, commitment/civil work becomes gainful employment. The risk of falling out of an adequate level of citizenship is diminishing and people still find themselves in a middle class community. The external effect and thereby the perception of being part of the middle class is maintained.

In the case of Mr Winkler, already cited, over-indebtedness is caused by an entrepreneurial (self) over-indebtedness, which then leads to unemployment. His former occupations (self-employed in the solar energy sector and graphic designer) are still important to Mr Winkler, especially at a time when the status of a middle-class worker is threatened and the profession or self-employment can no longer be exercised. The activities are synonymous with being active and thus a self-image of the active participant in the society. Mr Winkler is less interested in the content of the profession than in not being idle and showing it. He is now looking for alternatives to the activities in order to be able to continue to fulfil himself and others as a valuable active member of society: he works voluntarily in a welfare organisation:

I work very hard at the welfare organisation (...) in any way I can. The general public pays taxes which is where my money comes from to give anything back not that they're doing it for nothing... (22m2/90).

Mr Winkler wants to compensate his work for the support he receives from the state/society as an aid recipient (within the framework of the insolvency): the active commitment can be interpreted as a service, which should continue to reflect being middle class. He wants to be thought of as being the same (in value) as others in the middle class as before (i.e., before the insolvency). Anything else would be 'weakness', which would lead to a visible descent into another class. He shows no weakness or passive need. Mr Winkler sticks to what he wants to be, as he defines himself as part of his class. He does this by indicating that he remains the same because he continues and does not let himself go:

But they see that it didn't ruin me, that I continue nevertheless $(22 \mathrm{~m} 3 / 109)$.

8 Original quotations have been translated by the authors. 
He thus follows the mode of the market or work society softened with new forms of civil engagement, because it is important to him to remain as he is, and not to be different by what he sees as new (precarious) conditions/circumstances as the basis of his identity. This is not necessary: he does not have to deal with any concept of 'completely different' economics, exchange, or merely passive reception. He does not enter into an alternative culture, but takes up what is offered to him as a status-dependent member of society, that is, to be able to enter the regular and 'honest' labour market via the conventional honorary office:

I'm just trying to get a job using this way (.) In the free economy, it's just hard for me (.) And I'm just trying to do it with the welfare organisation with all the training I can get there (.) That then I then have the opportunity (.) to get back on my feet professionally/use it as a way in ehm I think it'll happen (.) I also like the people better they all know me (mhm) they know what I'm like they know oh he can do it, he can do that, we'll take him $(22 \mathrm{~m} 2 / 1033)$.

To behave honourably makes him successful in the eyes of his children. The fact that he is studying is rewarded with recognition:

Your dad does what? He may not be out of the house and working, but he's doing something. He's learning $(22 \mathrm{~m} 1 / 181)$.

Likewise, neighbours reward his constant activity:

They say you look good and you're doing something in the garden, they don't see that I need four days for gardening while others need half a day (22m1/96).

To name an honorary office as an alternative to previous work is essentially characterised by Mr Winkler's position and also by other interviewees.

\section{PRIVATE INSOLVENCY PROCEEDINGS AND CONFIDENCE IN INSTITUTIONAL ACTORS}

If we assume that over-indebtedness is perceived as a crisis that must be mitigated by middle-class behaviour such as the exercise of an honorary office or the demonstration of bourgeois commitment, the question arises as to how respondents perceive social and state institutions that bring confidence to counter this Cornia, Dressel and Pfeil [2016]. There are clear differences in the perception of the state, the legal system, the bailiff as an exercising power in the proceedings as well as other institutional actors such as banks, insolvency representatives, etc.

An example of this is the Pohl family. After a non-controlled, and in most cases barely anticipated, line of debt has been exceeded, the bank presents itself as an institution that does not tolerate debt. There are bank fluctuations, because 
interviewees feel strangled by the bankers. For example, Mr Pohl believes that he has to protect his money against the bank, he does not escape the attachment to a second bank, nor can he evade being recognised as a debtor by his employer $(24 \mathrm{~m} 1 / 173)$. Ms Lang experienced a similar treatment by the bank as a personal disappointment, when shifting a loan with an excessive interest rate:

That was really negligent what they did (...) It was so mean because I said who I was in good faith, I signed everything and thought they would help me (9w1/352).

This happens because institutions are no longer reliable: banks as former professional lenders have been enticed into indebting themselves, they have presented debt-making as normality. The state, which encourages people to invest in oneself and to cooperate with the financial market, acts as an institution that threatens with penalties for non-payment of debts. Society or the state as a generalised other shouts, you have to insure yourself $(2 \mathrm{w} 1 / 806)$. Something is required; if you do not follow the demand they'll try to dig your grave $(2 \mathrm{w} 1 / 787)$. Previously supported behaviours have become invalid.

While some are trying to find their own solutions for themselves, for instance by exercising an honorary office and by redefining their own situation with the limitations of state intervention, such as the above-mentioned Mr Winkler, others are strongly oriented to the state opportunities and gladly make use of the framework that is at their disposal as well as existing support opportunities. Interviewees who see only a small amount of manoeuvre for themselves for their own actions and feel helplessly exposed to a system are less able to deal actively and positively with these circumstances - after they have previously ignored all warnings from banks and bailiffs. These attitudes are also varying not only between the interviewees but show that the attitude to the state and state interventions change over time. In general, while in the phase of overindebtedness and before the possibility of private insolvency is considered, the state with its representatives appears to be a threat, sometimes an opponent, who urges, warns, and demands. A change takes place regarding this perception when private insolvency proceedings are initiated. Here is consistently found that the interviewees consider the private insolvency procedure, which gives them the opportunity to make up their minds, to be extremely positive and helpful. ${ }^{9}$ The state and its institutions are demanding for them, but at the same time they show an extremely long and exhausting path to be part of society again. In addition, the interviewees are sometimes treated unfairly and abandoned by the welfare state,

9 https://dejure.org/BGBl/2013/BGB1._I_S._2379 
complaining about the impositions on them by the procedure, and in contrast to other beneficiaries. While they "do nothing", they experience themselves as part of the active population, the middle class society.

Thus, the state and the various institutions involved in the insolvency process are perceived as quite contradictory: while on the one hand the feeling of being surrendered exists, on the other hand, the interviewees clearly perceive the opportunities of the process.

\section{ATTRIBUTION OF DEBT AND RESPONSIBILITIES IN THE PROCESS OF INSOLVENCY (BLAMING)}

It is not only the role of the state and the regulating authorities that the respondents perceive as different, but also the attribution of responsibility for their own situation. Who is responsible for the impending descent, for the restrictions imposed by private insolvency (blaming)? The way in which debt is attributed as a culturally established practice contributes to the normative consolidation of their own position as a middle-class member, which is found to be attacked. Even if over-indebtedness - unlike in the case of Cornia, Dressel and Pfeil [2016] or Douglas and Wildavsky [1982] - is dealt with individual crises, the question of responsibility arises. While in the case of catastrophes such as an accident in a chemical plant or even devastating storms such as the above-mentioned hurricane, the responsibility of the state (as the one who establishes the rules, perhaps not controlled, does not create sufficient precaution to protect citizens, etc.) is perceived as self-responsibility (how do I take precautions?) or as fate (and as a result of which self-perception can be experienced as a result of action), a differentiated and contradictory picture emerges in the case of the respondents.

Does the question of the responsibility and the guilt of the over-indebtedness in itself or the responsibility for the impending descent from the middle class apply? With the application of private insolvency, financial failure manifests, with its continuity being the real impact. In the increasing course of time, respondents are experiencing the limitations imposed on them by the procedure more and more. Self-evident components of a middle-class life such as mobility, education, consumption, or cultural participation are now becoming a rare asset. The experience of not being able to participate generates a lot of despair among the interviewees; they feel their middle-class identity is threatened. And here we also find blaming, which refers to the existing situation and concern for the descent from the middle class. This is no longer their own behaviour, not the behaviour of their husband, business partner, the bank, rather, the perspec- 
tive here is directed to the state and the impositions imposed upon them by the insolvency proceedings. This places too high demands on people: the duration is too long, the rules of conduct from the procedure too restrictive, support is too low. Not the over-indebtedness per se, but the implications of the procedure form the limits of belonging to the middle class for them. As a result, the questions of the fairness of these requirements and the lack of further support are posed and set as a delimitation against "below", against their own middle-class values. Most compatible to these outcomes are the versions described by Haus ${ }^{10}$ [2015] of how the middle class handles its situation, e.g. the plundering interpretation (as a reference to the discourse about the middle class as the actual support of the welfare state for which nothing is done from the part of the state, while for others much is done) or the so-called 'Prekarisierung' interpretation (the fear of becoming under class).

These categories describe what our study group discloses when they present themselves in their own over-indebtedness situation. The responsibility for the over-indebtedness of some respondents is quite self-critical:

We always had like blinkers. Somehow it will work and then he bought me a blouse, come on, it is only two Euros set on the top of the rates (...) and consequently the rates got higher and higher (...) I would say for me it was like an addiction (1w1/16).

This responsibility is ascribed to one's own consumer behaviour as well as in the case of Mr Winkler quoted above, to a result of wrong decisions (since the real reason is his serious illness and thus the impossibility of revising it) and thus his own action, his own responsibility; the reasons are usually different. Others blame the state, the insolvency administrator, the banks as well as the closer environment, be it business partners or even family.

And here the inconsistency of the situation becomes clear. Respondents perceive themselves as part of the middle class with shared values and norms such as the above-mentioned aspect of participation in active society, or in honorary office, they see themselves committed to the activating state with the requirement of an individual community orientation and as a bearer of values such as diligence, honesty, commitment, leadership, and social participation. At the same time, however, they feel marginalised because they can only implement middle--class actions such as decision-making autonomy, financial autonomy, and cultural education through the intervention of the state mostly with difficulty or not at all.

10 We are dealing here with interpretive patterns which describe the relationship between the welfare state and the middle class. 


\section{CONCLUSION}

One (and by no means the only) strategy to deal with fear of exclusion is to revert to 'real' values. Values that others seem to have forgotten: to be a good person. This is in contrast to self-images that have become obsolete. ${ }^{11}$ 'Reversion' means that the respondents have to follow (self-) identification or positions that were already there (known), but because of socialisation into real world, that is personal and occupational contexts of a market of self-assertion(s) they had to orient this way. With the focus on forgotten, conservative, and 'truly' good values, the respondents do not enter into a new world. Rather, they are drawn back to what was already and always there, but never - as it 'actually' should be - enforced. This is because the good - in this case, for example, the non-economised, the family, the community - was superimposed by the values of individualised achievement, competition, or growth. Both directions find their place in the discourse about middle-class positioning.

Respondents are embedded in this social context of the competing perspectives on the (middle) class. What changes for them is the weighting of the orientation to the competing perspectives. What has remained after insolvency/overindebtedness is more important and is often to be found in the family, religion, or a good life. People retreat to what is left, and this is the immediate community (e.g. the family or the neighbourhood). If the world is (or has become) hostile and takes away material goods, the family or community helps. This retreat does not require any particular justification. It is only about the intensified resumption of seemingly existing views and positioning.

In view of the insolvency with which the respondents of our research are confronted, they are looking for 'new orientations'. They must also do so in the face of the changed situation in which they can barely participate in the life they have been accustomed to. These orientations are, however, partly not so new, but are embedded in well-known modes, e.g. of working-class society.

On the one hand, possibilities of reorientation are perceived and this is precisely in the context of the civil society commitment, which allows (self-) perception as a member of the middle class. Here, new perspectives can be linked to people who are also engaged, and at the same time specific relations can be established to people who need help, in a situation which is asymmetrical to the individual position of the respondent: More likely, the middle-class position can be maintained more easily because it is possible to introduce potential for a lower class.

${ }_{11}$ Or both have always been right next to each other. 
On the other hand, the interviewees succeed in describing themselves by way of delineation strategies to others in such a way that people are actually on the right path and represent the 'right' values of the middle class. Business partners, banks, insolvency administrators, and the state as such are accused of being jointly responsible for their own precarious situation. The established institutions dissociate themselves, which makes people's own situation more bearable, because it is accompanied by debt relief and forgiveness.

These findings are linked to other current political discussions. Problems are dealt with which address the middle class as support for the welfare state, inasmuch as it is no longer able to meet its demands as support. It is precisely with our investigation of middle-class members, who are confronted with a concrete problem situation (combined with the risk of falling out of their class), that we can find out something about how they re-form in the long term. This can be achieved by doing research over longer periods. Will middle-class members turn actively, politically against institutions which have become unreliable to them, and how do they do that in concrete terms? Do middle-class members find new associations, like-minded people, who struggle against the mainstream in the community (especially in the case of problems such as over-indebtedness and apprehension) - as is the case today in Germany in many respects? Or do they confine themselves to 'good' commitment, as we have seen in our study?

\section{REFERENCES}

Beck Ulrich. 1986. Risikogesellschaft. Frankfurt am Main: Suhrkamp

Berger Peter, Thomas Luckmann. 1969. Die gesellschaftliche Konstruktion der Wirklichkeit. Frankfurt am Main: Fischer.

Burzan Nicole, Silke Kohrs, Ivonne Küsters. 2014: Die Mitte der Gesellschaft: Sicherer als erwartet? Weinheim: Beltz Juventa.

Castel Robert. 2005. Die Stärkung des Sozialen. Leben im neuen Wohlfahrtsstaat. Hamburg: Hamburger Edition HIS.

Conradi Elisabeth. 2011. Kosmopolitische Zivilgesellschaft. Inklusion durch gelingendes Handeln. Frankfurt am Main/New York: Campus.

Cornia Alessio, Kerstin Dressel, Patricia Pfeil. 2016. "Risk cultures and dominant approaches towards disasters in seven European countries". Journal of Risk Research (19)3: 288-304.

Dengel Udo. 2014. Erfahrung verbindet. Die Potenziale älterer MigrantInnen im Tätigkeitsfeld des Migrations- und Integrationsengagements. Wiesbaden: VS Verlag.

Douglas Mary, Aaron Wildavsky. 1982. Risk and culture: An essay on the selection of technological and environmental dangers. Berkley: University of California Press.

Douglas Mary. 1992. Risk and blame: Essays in cultural theory. London: Routledge.

Douglas Mary. 2003. Purity and danger: An analysis of concept of pollution and taboo. London: Routledge. 
Entman Robert M. 2010. "Media framing biases and political power: Explaining clant in news of campaign 2008". Journalism 11(4): 389-408.

Habermas Jürgen. 1994[1992]. Faktizität und Geltung. Beiträge zur Diskurstheorie des Rechts und des demokratischen Rechtsstaats. Frankfurt am Main: Suhrkamp.

Hacket Anne, Cedric Janowicz, Irene Kühnlein. 2004. Erwerbsarbeit, bürgerschaftliches Engagement und Eigenarbeit. In: Entgrenzung und Entscheidung. Was ist neu an der Theorie reflexiver Modernisierung? U. Beck, C. Lau (eds.), 281-306. Frankfurt am Main: Suhrkamp.

Halvorsen Knut. 1998. "Symbolic purposes and factual consequences of the concepts 'self-reliance' and 'dependency' in contemporary discourses on welfare”. Scandinavian Journal of Social Welfare 7: 56-64.

Hardil Stefan. 2000. Soziale Ungleichheit, soziale Schichtung, Mobilität. In: Einführung in Hauptbegriffe der Soziologie. H. Korte, B. Schäfers (eds.), Kap XI. Opladen: Leske + Budrich.

Haus Michael. 2015. "Mittelschicht und Wohlfahrtsstaat - Drei Deutungsmuster und ihre Relevanz für die Zukunft eines wohlfahrtsstaatlichen Grundkonsenses". Zeitschrift für Sozialreform 61(2): 147-170.

Heidbrink Ludger. 2006. Einleitung: Verantwortung in der Zivilgesellschaft. Zur Konjunktur eines widersprüchlichen Prinzips. In: Verantwortung in der Zivilgesellschaft. Zur Konjunktur eines widersprüchlichen Prinzips. A. Hirsch, L. Heidbrink (eds.), 13-39. Frankfurt am Main: Campus.

Lessenich Stephan. 2009. "Das Elend der Mittelschichten. Die 'Mitte' als Chiffre gesellschaftlicher Transformation“. WIDERSPRÜCHE. Zeitschrift für sozialistische Politik im Bildungs-, Gesundheits- und Sozialbereich 111(29/1): 19-28.

Lessenich Stephan. 2016. "Die Mitte ein hochgradig gefährdeter Ort”. Süddeutsche Zeitung 23. Juni 2016. http://www.sueddeutsche.de/kultur/serie-mittelschicht-die-mitte-ein-hochgradiggefaehrdeter-ort-1.3047923 [access: 18.09.2017].

Lupton Deborah. 1999. Risk. London: Routledge.

Maaser Wolfgang. 2006. Aktivierung der Verantwortung. Vom Wohlfahrtsstaat zur Wohlfahrtsgesellschaft. In: Verantwortung in der Zivilgesellschaft. Zur Konjunktur eines widersprüchlichen Prinzips. A. Hirsch, L. Heidbrink (eds.), 61-84. Frankfurt am Main: Campus.

Müller Marion, Patricia Pfeil, Udo Dengel, Lisa Donath. 2017. Identität unter Druck. Überschuldung in der Mittelschicht. Wiesbaden: VS Verlag.

Munsch Chantal. 2003. Sozial Benachteiligte engagieren sich doch. Über lokales Engagement und soziale Ausgrenzung und die Schwierigkeiten der Gemeinwesenarbeit. Weinheim: Juventa.

Nachtwey Oliver. 2016. Die Abstiegsgesellschaft. Über das Aufbegehren in der regressiven Moderne. Berlin: Suhrkamp.

Olk Thomas, Birger Hartnuß. 2011. Bürgerschaftliches Engagement. In: Bürgerschaftliches Engagement Handbuch. B. Hartnuß, T. Olk (eds.), 145-161. Weinheim: Beltz Juventa.

Pfeil Patricia, Marion Müller, Lisa Donath, Udo Dengel. 2015. Insolvenz als Endpunkt oder als Anfang? Leben in Überschuldung in einer finanzialisierten Alltagswelt. Zeitschrift für Sozialreform 61(3): 291-313.

Schulze Gerhard. 1995. Die Erlebnis-Gesellschaft. Frankfurt/ Main, New York: Campus Verlag.

Scott Alan. 2005. Risk society or Angst society? Two views of risk, consciousness and community. In: The risk society and beyond. Critical issues for social theory. B. Adam, U. Beck, J. van Loon (eds.), 33-46. London: Sage Publications.

Strauss, Anselm L. Juliette Corbin (1996). Grundlagen qualitativer Sozialforschung. Weinheim: Beltz Psychologie Verlags Union. 
Tansey James, Tim O'Riordan. 1999. "Cultural theory and risk: A review". Health, Risk \& Society 1 (1): 71-90.

Tulloch John. 2008. Culture and risk. In: Social theories of risk and uncertainty: An introduction. J.O. Zinn, (ed.), 138-67. Oxford: Blackwell.

Van Loon Joost. 2003. Risk and technological culture: Towards a sociology of virulence. London: Routledge.

Vester Michael. 2001. Soziale Milieus im gesellschaftlichen Strukturwandel. Zwischen Integration und Ausgrenzung. Dordrecht, Boston, London: Kluwer Academic Publishers.

Vogel Berthold. 2010. Wohlstandspanik und Statusbeflissenheit. Perspektiven auf die nervöse Mitte der Gesellschaft. In: Dynamiken (in) der gesellschaftlichen Mitte, N. Burzan, P.A. Berger (eds.), 23-41. Wiesbaden: VS Verlag.

Wynne Brian. 1992. Risk and social learning: Reification to engagement. In: Social theories of risks, S. Krimsky, D. Golding (eds.), 275-297. Westport CT: Praeger.

Zinn Jens O. (ed.). 2008. Social theories of risk and uncertainty: An introduction. Oxford: Blackwell.

Patricia Pfeil

Udo Dengel

Marion Müller

\section{KULTUROWO-SPECYFICZNE WYMIARY SPOLECZNEJ (RE-)FORMACJI (PRZEKSZTALCENIA) KLASY ŚREDNIEJ W NIEMCZECH}

\section{Streszczenie}

Artykuł przedstawia sposoby re-formacji (przekształcenia) klasy średniej w Niemczech, które zostały spowodowane przez postrzeganie społecznych (i indywidualnych) kryzysów (w prezentowanym przez nas przykładzie - nadmiernego zadłużenia) i związanej z nimi niepewności. Jakie są strategie, które rozwinęli członkowie klasy średniej, żeby poradzić sobie z postrzeganymi kryzysami i jakie czynniki przyczyniły się do powstania nowych form społecznych (obywatelskich)? W tym kontekście, podkreślamy wagę wpływu kulturowo-specyficznych wzorów orientacji w odniesieniu do specyficznych grup społecznych. Przywołujemy prace Douglas i Wildavsky'ego [1982], a także Cornia, Dressel i Pfeil [2016] i skupiamy się na zbiorowym wymiarze, kiedy stawiamy pytanie: Jak klasa średnia i jej części (podgrupy) - w naszym przykładzie osoby nadmiernie zadłużone - postrzegają i interpretują rozwój społeczny oraz kryzysy (ramowanie/framing)? Jaki jest związek pomiędzy klasą średnią oraz aktorami instytucjonalnymi w zakresie pokładanego w nich przez klasę średnią zaufania, zwłaszcza w odniesieniu do radzenia sobie z kryzysami społecznymi i związanymi z tym stosowanymi rozwiązaniami? Kogo członkowie klasy średniej winią za te kryzysy i ryzyko społecznej degradacji (obwinianie/blaming)? Jest to centralne pytanie bezpośrednio związane ze sposobami radzenia sobie z ryzykiem i przyjmowanym założeniem o (kierunku) odpowiedzialności.

Słowa kluczowe: klasa średnia, kryzys społeczny, nadmierne zadłużenie, re-formacja, niemiecka klasa średnia, kulturowo-specyficzne wymiary, społeczeństwo obywatelskie, ryzyko społeczne 